\title{
A broken vow: an examination of the cases of Corruption in the Philippines
}

Um voto quebrado: um exame dos casos de corrupção nas Filipinas

Un voto roto: un examen de los casos de corrupción en Filipinas

Christian F. Gonzales

Christian.f.Gonzales@isu.edu.ph

Isabela State University - Cauayan Campus - Philippines

ORCID: https://orcid.org/0000-0002-7712-359X

\begin{abstract}
The problem of corruption in the Philippines seems to be humongous as if no solution is available for its cure. This study used a descriptive and qualitative research design. It exposed the anti-corruption laws and the cases decided by the various Philippine courts. It found out that even with the existence of laws as well as the removal or the conviction of several government officials and employees, corrupt practices seem to be undeterred. The continuance of corruption in the country resulted to the promise of President Duterte to be a broken vow.
\end{abstract}

Keywords: Corruption. Corrupt Practices. President Duterte. Broken Vow. Philippines.

\section{RESUMO}

O problema da corrupção nas Filipinas parece ser enorme, como se nenhuma solução estivesse disponível para sua cura. Este estudo utilizou um desenho de pesquisa descritiva e qualitativa. Expôs as leis anticorrupção e os casos decididos pelos vários tribunais filipinos. Constatou-se que mesmo com a existência de leis, bem como com a remoção ou condenação de vários funcionários e funcionários do governo, as práticas corruptas parecem não se intimidar. A continuação da corrupção no país resultou na promessa do presidente Duterte de ser um voto quebrado.

Palavras-chave: Corrupção, Práticas Corruptas, Presidente Duterte, Juramento Quebrado. Filipinas.

\section{RESUMEN}

El problema de la corrupción en Filipinas parece ser enorme, como si no hubiera una solución disponible para su cura. Este estudio utilizó un diseño de investigación descriptivo y cualitativo. Expuso las leyes anticorrupción y los casos decididos por los distintos tribunales filipinos. Descubrió que incluso con la existencia de leyes, así como con la destitución o la condena de varios funcionarios y empleados del gobierno, las prácticas corruptas parecen no dejarse intimidar. La continuidad de la corrupción en el país resultó en la promesa del presidente Duterte de ser un voto roto.

Palabras clave: Corrupción. Prácticas Corruptas. Presidente Duterte. Juramento Roto. Filipinas.

\section{INTRODUCTION}

Most commonly, corruption is described as the misuse of public power for private benefit or gain. ${ }^{1}$ It is one of the most serious problems in the Philippines aside from high percentage rate of poverty, unemployment, criminality and illegal drugs. Charges of corruption became a common

\footnotetext{
${ }^{1}$ Ferrer, E. S., \& De Dios, R. D. (2001). Corruption in the Philippines: Framework and Context. Philippine Journal of Public Policy, 5(1), 1-42. Retrieved November 28, 2020, from https://cids.up.edu.ph/wp-content/uploads/Corruption-inthe-Philippines-vol.5-no.1-Jan-June-2001-2.pdf
} 
trend among government officials, from the lowest to the highest level. The Filipino people have even branded some government officials and employees as "buwaya" (crocodile). ${ }^{2}$ As a matter of fact, it is a common misconception among the people that all who work in the government are corrupt.

Historical interpretations of corruption in the Philippines attribute this malady to the colonial experiences. This suggests that corrupt practices in the country form part of a repertoire of behavior that Filipinos learned and acquired from their colonial masters: the Spaniards and the Americans. ${ }^{3}$ In the administrations of former Presidents Ferdinand Marcos and Gloria Macapagal-Arroyo, the Bataan Nuclear Power Plant (BNPP) scandal and the National Broadband Network and China's ZTE Company Contract (NBN-ZTE Deal), respectively, were identified by a research report as the largest cases of corruption involving the highest officials of the country. ${ }^{4}$

Despite the convictions of several government officials, as if nothing has changed. Every single day, Filipinos are still bombarded with daily news of corruption here and there. In fact, from 1995 until 2019, the Corruption Rank in Philippines averaged 93.96, the all-time high of in 2008 was 141 and the record low in 1995 was $36 .{ }^{5}$

During the Presidential campaign in 2016, then Mayor Rodrigo Roa Duterte of Davao City acknowledged that he could not guarantee heaven to the Filipino people but he, again and again, retold his promise to bring an end to criminality, illicit drugs and political corruption ${ }^{6}$ in the government within the first six months if he gets elected to the highest office. ${ }^{7}$ He even assured the people that had he failed to do so, then he would resign. ${ }^{8}$ As Filipinos were quite upset with the Aquino (PNoy) 9 Administration's failure to fulfill its promise of a "tuwid na daan" 10 and were so fed up with the perennial problems of high criminality rates, proliferation of drug syndicates, as well as the rampant corruption in the government, Duterte was elected to Presidency by 16 million voters. ${ }^{11}$ There were high hopes and expectations that he would finally accomplish what his predecessors were not able to do.

Risk and Compliance Portal described that high corruption severely restrict efficiency in the Philippines. This includes extensive bribery, extortion and manipulation among the government officials and employees from among the three main branches of the government: Executive, Legislative and Judiciary. ${ }^{12}$

This object of this paper is to examine the corruption cases in the Philippines and the broken vow of the President to finally end it. In so doing, this paper is subdivided into five parts. Each one

\footnotetext{
${ }^{2}$ In Filipino colloquial term, "buwaya" is associated to greed and insatiability. Here it means greed and insatiability when it comes to money, position or power.

${ }^{3}$ Endriga, J. N. (1979). Historical Notes on Graft and Corruption. Philippine Journal of Public Administration, Volume XXIII (Nos. 3 and 4), 241-254. Retrieved November 28, 2020, from https://pssc.org.ph/wp-content/psscarchives/Philippine\%20Journal\%20of\%20Public\%20Administration/1979/Num\%203-

4/06_Historical\%20Notes\%20on\%20Graft\%20and\%20Corruption\%20in\%20the\%20Phils..pdf

4 Batalla, E. V. (2020). Grand corruption scandals in the Philippines. Emerald Insight, 23(1), 73-86. doi: https://doi.org/10.1108/PAP-11-2019-0036

Trading Economics. (2019). Philippines Corruption Rank 1995-2019. Retrieved from https://tradingeconomics.com/philippines/corruption-rank

${ }^{6}$ Emphasis supplied.

${ }^{7}$ Corrales, N. (2016, March 20). Duterte: 'I can't promise heaven, but I will stop corruption'. Retrieved November 27 , 2020, from Inquirer.Net: https://newsinfo.inquirer.net/775352/duterte-i-cant-promise-heaven-but-i-will-stop-corruption

${ }^{8}$ Tejada, A. P. (2016). Duterte vows to end criminality in 3 months. Retrieved December 5, 2020, from The Philippine Star: https://www.philstar.com/headlines/2016/02/20/1555349/duterte-vows-end-criminality-3-months

${ }^{9}$ PNoy was the nickname given by the Philippine media to the former President Benigno Simeon S. Aquino III.

10 "Tuwid na Daan" was the tagline of the PNoy Administration. It is literally translated as Straight Path. It is a flamboyant play of words used by PNoy to stress its advocacy and promise to the people of a better government and a much more righteous governance compare to his predecessors.

${ }^{11}$ It represents the $38 \%$ of the voting populace in 2016 and is the highest number of votes that a candidate garnered in the history of Philippine Presidential election.

12 Risk and Compliance Portal. (2020). The Philippines Corruption Report. Retrieved from Gan Integrity: https://www.ganintegrity.com/portal/country-profiles/the-philippines/
} 
was discussed to give the readers not just an overview of, but as well as a clearer picture of the existing laws formulated to penalize corrupt practices in the Philippines, various cases decided by the Supreme Court, the Sandiganbayan and the Office of the Ombudsman, the biggest corruption controversies involving government officials and employees as well as several Duterte appointees, and an analysis of the studies made by various scholars on corruption.

Part I discussed Article XI of the 1987 Constitution which pertains to the Accountability of Public Officers. Part II gave an in-depth discussion of the Anti-Graft and Corrupt Practices Act, particularly Section 3. Part III focused on the Revised Penal Code's provisions on bribery and malversation. Part IV offered a discourse on the Code of Conduct and Ethical Standards for Public Officials and Employees. Finally, Part V exposed of the biggest headlined corrupt practices under the Duterte Administration which made the promise of the President to end corruption a broken vow.

\section{METHODS}

This paper used exposition, evaluation, and descriptive method of research. It discussed the laws in the Philippines which are designed to penalize the corrupt practices committed by government officials, employees as well as private persons, and some notable decisions on corruption cases rendered by the Supreme Court and the Sandiganbayan. Mainly, it delved into an examination of the cases of corruption in the Philippines (during the past administrations as well as the present), and the broken vow made by President Duterte to finally end this perennial problem that the country has.

\subsection{ARGUMENT}

Specifically, this paper argues that despite the existence of the Constitutional provisions on Accountability of Public Officers, together with the Anti-Graft and Corrupt Practices $\mathrm{Act}^{13}$, the provisions of the Revised Penal Code defining and penalizing corrupt practices ${ }^{14}$, the Code of Conduct and Ethical Standards for Public Officials and Employees ${ }^{15}$, and the huge number of removal of, as well as the conviction of, government officials and employees rendered by the courts, corruption still seems to be institutionally normalized in the government. It seems to be an insoluble malady in the government that no law could ever deter.

\section{RESULTS AND DISCUSSION}

\subsection{ACCOUNTABILITY OF PUBLIC OFFICERS}

\section{A. Historical Background}

In the case of Biraogo, the Constitution is defined as the fundamental and supreme law to which all laws must adhere and all persons must submit, including the highest officials of the country. ${ }^{16}$ It is, with particular reference to the Constitution of the Philippines, a written document passed through the direct intervention of the people by which the fundamental powers of the government are created, restricted and specified and by which those powers are divided among the

\footnotetext{
${ }^{13}$ See Republic Act No. 3019, approved in 1960.

${ }^{14}$ See Title VII Chapter II Section 2 and Chapter IV.

${ }^{15}$ See Republic Act No. 6713, approved in 1989.

${ }^{16}$ See G.R. No. 192935, December 7, 2010.
} 
different departments for the sake of their secure and useful exercise for the benefit of the political body. ${ }^{17}$

Among the twenty-eight (28) articles composing the present 1987 Constitution, one from which provides for the provisions relating to the accountability of public officers.

The provisions pertaining to the accountability of public officers actually first came out in the 1973 Philippine Constitution. ${ }^{18}$ It is a big development during that time since the previous ones, particularly the original and the amended 1935 and the 1943 Constitutions did not include such provisions. The provision for impeachment in the 1935 and the 1943 Constitutions only specified certain public officials covered in its parameters. For the 1935 Constitution, only the President, the Vice-President, the Justices of the Supreme Court, and the Auditor General, may, on indictment, be suspended from office for any prosecution, breach of the Constitution, treason, corruption, or other serious offenses. ${ }^{19}$ On the other hand, for the 1943 Constitution, it is only the President and the Supreme Court Justices who may be suspended from office on trial for, and conviction of, a guilty breach of the Constitution, treason, theft, or other serious offenses. ${ }^{20}$

While it is true that the 1973 Constitution defines the accountability of government officials, only the President, the Justices of the Supreme Court and the Members of the Constitutional Commissions have been enumerated as such who may be removed from office through impeachment, or through a judgment of conviction for breach of the Constitution, for acceptance of bribe money, for the performance of treason and other higher crimes, or the commission of graft and corruption..$^{21}$ It failed to talk about other government officials and employees.

The current Philippine Constitution defines public office as a public trust and requires public officials and employees to be accountable to the people at all times, to serve them with utmost responsibility, integrity, loyalty, and efficiency; to behave with patriotism and justice, and to lead modest lives. $^{22}$ It maintained the possible removal, through impeachment, of the President, the members of the Supreme Court and the Constitutional Commissions, adding the Vice-President and the Ombudsman as officers who could also be removed by the same process. It is also claimed that in the manner established by statute, but not by impeachment, all other elected and appointed officials may be removed and be disqualified from office. ${ }^{23}$ It is to note that among the constitutions which took effect in the country, it is only the present Constitution which specifies graft and corruption as a ground for removal of all public officers through impeachment and conviction thereof, or through a manner provided by law.

\section{B. Impeachment}

The impeachment process is characterized as a national investigation into the actions of public men. ${ }^{24}$ It is a system intended to regulate power exploitation that has its origins in Athens and was introduced in the United States by the effect of common English law on the framers of the United States Constitution. ${ }^{25}$ In the case of former Chief Justice Renato Corona v. Senate of the Philippines, impeachment was defined as the authority of Congress, as given in the Constitution, to oust a public official for serious crimes or wrongdoing.

\footnotetext{
${ }^{17}$ Malcolm, G. A. (1926). Philippine Constitutional Law 2nd Edition. Manila: P.I. \& Rochester, NY, Lawyers Co-op.

18 See Article XIII, 1973 Constitution.

${ }^{19}$ See Article IX Section 1, 1935 Constitution.

${ }^{20}$ See Article V Section 1, 1943 Constitution.

${ }^{21}$ See Article XXIII Section 2, 1973 Constitution

${ }^{22}$ See Article XI Section 1,1987 Constitution.

${ }^{23}$ See Article XI Section 2, 1987 Constitution.

${ }^{24}$ Nachura, A. E. (2016). Outline Reviewer in Political Law. p.434. Quezon City: VJ Graphic Arts, Inc.

${ }^{25}$ Ibid., p. 434.
} 
Just the impeachable officials are enumerated in the Constitution: the President, the VicePresident, the judges of the Supreme Court, the members of the Judicial Commissions and the Ombudsman on the basis of guilty breaches of the Constitution, treason, bribery, graft and corruption, other serious offenses or betrayal of public trust. ${ }^{26}$ This means that no other public officers may be impeached except those enumerated and on the said grounds.

\section{B.1. The Impeachment of Philippine Public Officials ${ }^{27}$}

History narrates that impeachment complaints were filed as early as the year 1949 when Juan Rodriguez filed an impeachment suit against President Elpidio S. Quirino on April 28 of that year, alleging waste and misappropriation of public funds; misuse of authority, breach of rules, and unethical extravagance; interference prejudicial to the public interest in the transaction in which his brother Antonio was in connivance with a Soviet citizen; endorsing and promoting bribery and corruption; and gross social misconduct and acts, which denied the government of significant revenue as grounds thereof. Nevertheless, because of a lack of credible and legal basis, these allegations were dismissed on April 29, 1949.

Rep. Arturo M. Tolentino charged President Diosdado Macapagal in 1964 with alleged illicit importation of rice for the Armed Forces and an infringement of the Anti-Graft and Corrupt Practices Act. However, in June 24 of the same year, these charges were dismissed in the committee level.

On August 13, 1985, a group of fifty-eight (58) opposition lawmakers filed an impeachment complaint against President Ferdinand E. Marcos. They charged Marcos of graft, plunder, mysterious affluence, cronyism, among other abuses. As the National Assembly (now, Congress) was largely held by Marcos, the resolution was immediately rejected seven hours after submission for being insufficient in form and in substance.

In 2000, President Joseph Ejercito Estrada (Erap) was charged with graft and theft, betrayal of public trust and guilty violations of the Constitution by the Opposition Bloc of the HOR, headed by House Minority Leader Feliciano Belmonte Jr. He was the first official to be impeached. However, after the public prosecutors walked out, the impeachment trial concluded on January 16, 2001, when 11 of the 21 Senator-Judges of the IC voted not to open the envelope that was rumored to prove that Erap had deposited 500 million pesos in a bank account that was later used for gambling. Soon after the decision was announced, Archbishop Jaime Cardinal $\operatorname{Sin}^{28}$ encouraged the people to flock at the Epifanio de los Santos Avenue (EDSA) in Quezon City which would later be called EDSA II or the People Power II. On the third day of the demonstration, more than two million demonstrators, as well as many police and military leaders, had assembled to demonstrate that there would be no strong resistance to deter or listen to them. This led to President Erap's ouster.

On November 6, 2001, a certain Ernesto Francisco had filed an impeachment compliant against Ombudsman Aniano Desierto charging him with bribery, culpable violations of the Constitution and betrayal of public trust. The case was nevertheless dismissed on December 18, 2001.

\footnotetext{
${ }^{26}$ See Article XI Section 2, 1987 Constitution.

${ }^{27}$ See Impeachment: A Political and Historical Guide. (2014). Retrieved from GOV.PH: https://www.gov.ph/documents/20147/233614/ImpeachmentPrimer.pdf/72801f41-71e1-ae60-d5bbc69dbf622994? version $=1.0$

${ }^{28}$ Known as Cardinal Sin, he was a very influential Church leader who also called upon the people to rise up and gather at EDSA to overthrow the then dictator Ferdinand E. Marcos.
} 
In 2003, Chief Justice Hilario Davide, who presided the impeachment trial of former President Erap, was charged with graft and corruption in an impeachment case filed by Representative Felix Fuentabella and Erap himself. However, after the House plenary voted not to transmit the AIs to the Senate, it was rejected on November 19, 2003.

Oliver Lozano and Jose Lopez filed a complaint against former President Gloria MacapagalArroyo (PGMA) for culpable violations of the Constitution, graft and corruption, bribery, and betrayal of public trust. The case was nonetheless dismissed on August 31, 2005 on grounds of the insufficiency in substance of the complaint. In 2006, twelve (12) impeachment complaints were filed against PGMA citing cheating, corruption, political persecution, extrajudicial killings, and violation of the Constitution as grounds thereof. All of them were dismissed on August 26, 2006. The 2007 impeachment complaint filed by Roberto Rafael Pulido was also dismissed. And in 2008, another impeachment case was filed by Harry Roque, Joey de Venecia, and Rolex Suplico as endorsed by some representatives of Bayan Muna and Gabriella. ${ }^{29}$ On the same year, it was also dismissed.

On September 27, 2007, an impeachment complaint was filed against former Chairman Benjamin Abalos Sr. Commission of the Elections (COMELEC) by Iloilo Vice-Governor Rolex Sulpico and citing graft and corruption, culpable violation of the Constitution, bribery and betrayal of the public trust as grounds thereof. ${ }^{30}$ This complaint was related to the allegations of bribery and corruption in connection with the ZTE-NBN deal. However, on October 1 of the same year, Chairman Abalos resigned and said in a press conference that he did so to protect the COMELEC from malicious attacks against his person. ${ }^{31}$

Thirty-one (31) civil society leaders led by former Senate President Jovito Salonga and party-lists Akbayan and Bagong Alyansang Makabayan charged Ombudsman Merceditas Gutierrez in 2009 and 2010 of impeachment complaints. Her impeachment was declared on March 22, 2011. However, on April 29 of the same year and just 10 days before she was due to face impeachment trial in the Senate, she resigned leaving the Senate not to be embroiled in hearings and depriving the country of an opportunity for a public examination of the allegations of corruption against the previous President, Gloria Macapagal-Arroyo. ${ }^{32}$

On December 12, 2011, an impeachment complaint against Chief Justice Renato Corona (CJ Corona) was filed by Rissa Hontiveros, Lea Lopez Navarro, Jun Lozada, and Juan Tejano citing graft and corruption, culpable violation of the Constitution, and betrayal of public trust as grounds thereof. On December 13, 2011, he was impeached and the AIs were submitted to the Senate immediately. It was on January 16, 2012 when the trial began. By a vote of 20-3 favoring his conviction, he was removed from office on the $29^{\text {th }}$ day of May 2012,

On October 11 2017, the COMELEC chairman Andres D. Bautista was charged of an impeachment complaint by Harry Roque and Jacinto Paras on grounds of betrayal of public trust, graft and corruption and bribery. The members of the House Justice Committee (HJC) dismissed the impeachment complaint for having a defective verification form. However, the member of the HOR with a vote of 137-75-2 overturned the decision of the HJC and impeached him. ${ }^{33}$ On the same day, he tendered his resignation letter which was supposed to take effect by December 31,

\footnotetext{
${ }^{29}$ Bayan Muna and Gabriella are party-list in the Philippines which hold seats in the House of Representatives.

${ }^{30}$ Diaz, J. (2008). Abalos faces impeachment. PhilStar Global, p. not applicable. Retrieved November 30, 2020, from https://www.philstar.com/headlines/2007/09/28/16994/abalos-faces-impeachment

${ }^{31}$ Conde, C. H. (2007, October 1). Benjamin Abalos, Filipino elections official, resigns in a scandal that may threaten Arroyo. The New York Times, p. not applicable. Retrieved November 30, 2020, from https://www.nytimes.com/2007/10/01/world/asia/01iht-phils.1.7696723.html

32 EIU. (2001, June 1). The Economist Intelligence Unit. Retrieved November 30, 2020, from The Economist Group: http://country.eiu.com/article.aspx ?articleid=1628143747\&Country=Philippines\&topic=Politics\&subtopic=Recent+develo pments\&subsubtopic $=$ The+political+scene:+Merceditas+Gutierrez+resigns+as+ombudsman

${ }^{33}$ Uy, J. R., Santos, T. G., \& Nonato, V. F. (2017). House impeaches Comelec chief after he said he was resigning. Inquirer.Net, p. not applicable. Retrieved November 30, 2020, from https://newsinfo.inquirer.net/937198/house-votes-toimpeach-bautista
} 
2017 to President Rodrigo Roa Duterte. His resignation was accepted earlier than expected on October 23, 2017. ${ }^{34}$

On March 16, 2017, the opposition lawmaker, Gary Alejano filed an impeachment complaint against President Duterte and charging him of corruption, mass murder and crimes against humanity. ${ }^{35}$ However, at the first hearing, the Justice Committee of the House of Representatives, which is dominated by Duterte's supporters, announced that there was insufficient substance for the impeachment case to continue. ${ }^{36}$

In 2018, the HJC approved the Six (6) Articles of Impeachment against Chief Justice Maria Lourdes Sereno. She did not, though, stand justice before the IC, but was ousted by the Supreme Court by a 9-5 vote in favor of Solicitor General Jose Calida's Quo Warranto petition. ${ }^{37}$

Of all the impeachment complaints filed against the abovementioned impeachable officers, it can be gleaned that almost all cited graft and corruption, malversation and bribery as grounds thereof.

\subsection{REPUBLIC ACT 3019 AND SOME DECIDED CASES}

\section{A. Section 3, R.A. No. 3019}

The law on Anti-Graft and Corrupt Practices prescribes specific penalties for the corrupt practices made by a public officer, that is, a government official or employee, as well as private individuals. A public officer includes elective and nominating officers and staff, permanent or temporary, receiving pay, even minimal, from the government, whether in a classified or unclassified or excluded service. $^{38}$

This subpart discusses the corrupt practices that may be committed by any public officer:

\section{A.1. Section 3(b)}

Violation of this section is performed by a public officer who, directly or indirectly, orders or collects for himself or any other individual any gift, present, share, percentage or profit in connection with any arrangement or exchange between the Government and any other party to which the public officer, in his capacity as official, is required to interfere under the law. In Preclaro v. Sandiganbayan, the Court has stressed that failure to receive the gift requested is not a defense. ${ }^{39}$ Receiving a gift shall likewise consummate the crime even with the absence of a request.

\section{A.4. Section 3(c)}

\footnotetext{
${ }^{34}$ CNN Staff, Philippines. (2017). Malacañang: Bautista's resignation 'effective immediately. Retrieved November 30, 2020, from CNN Philippines: https://cnnphilippines.com/news/2017/10/23/malcanang-andres-bautista-resignationeffective-immediately.html

${ }^{35}$ Villamor, F. (2017). Philippine Lawmaker Moves to Impeach Duterte. The New York Times, p. not applicable. Retrieved November 30, 2020, from https://www.nytimes.com/2017/03/16/world/asia/philippines-duterte-impeachment-.html ${ }^{36}$ Associated Press (2017). Philippine lawmakers kill impeachment case against Duterte. Retrieved November 30, 2020, from: https://www.usatoday.com/story/news/world/2017/05/15/philippine-lawmakers-kill-impeachment-case-againstduterte/101700122/

${ }^{37}$ Merez, A., Quintos, P., Reformina, I., \& Manabat, J. (2018). Supreme Court ousts Chief Justice Sereno. Manila: ABSCBN News. Retrieved November 30, 2020, from https://news.abs-cbn.com/news/05/11/18/supreme-court-ousts-chiefjustice-sereno

${ }^{38}$ See Section 2(b), R.A. No. 3019.

${ }^{39}$ G.R. No. 111901, August 21, 1995.
} 
Violation of this Section shall be performed by any public officer who expressly or indirectly requires or receives, for himself or for another, any donation, present or other pecuniary or material gain from any person to whom the public officer, in any manner or capacity whatsoever, has secured or received, or will secure or obtain, any government permit or license in respect of the assistance rendered or to be issued.

In the Tecson v. Sandiganbayan ${ }^{40}$ a municipal mayor who signed and issued a Mayor's permit to the complainant, was held liable for requesting and receiving a certain amount of money to be used for the Fiesta celebration.

\section{A.4. Section 3(e)}

Violation of this section shall be committed by any public officer who, by apparent partiality, clear bad faith or gross inexcusable incompetence, causes any unfair harm to any entity, including the State, or gives any private party any unjustified benefit, advantage or preference in the discharge of his official administrative or judicial duties. This provision shall apply to officers and employees of offices or government corporations charged with the grant of licenses or permits or other concessions.

In Fuentes v. People of the Philippines, ${ }^{41}$ the Supreme Court affirmed the earlier decision of the Sandiganbayan to convict Mayor Fuentes for refusing for an unreasonable period of time to renew the business permit of Ship Chandling Services causing damage and prejudice to its owners. The Supreme Court also upheld the decision of the Sandiganbayan to convict the petitioner of accepting the award and release of the retirement gratuity and terminal leave benefits of the former president of the Philippine Crop Insurance Corporation (PCIC) in Tiongco v. People of the Philippines $^{42}$ of the Philippines, thus performing usurpation of public duties and causing unnecessary harm to the country.

\section{A.5. Section 3(f)}

Violation of this section is performed by any public official who, after having been properly requested or requested without adequate explanation, neglects or refuses to act within a reasonable period on any matter pending before him for the purpose of gaining, directly or indirectly, any financial or material benefit or advantage from any party involved in the matter, or for the purpose of favoring his own advantage.

In Lacap v. Sandiganbayan and the People of the Philippines, ${ }^{43}$ a high-ranking public officer was held liable for neglecting to act on a certain application for a Mayor's permit.

\section{A.7. Section 3(h)}

Violation of this section shall be performed by any public officer who, expressly or indirectly, has funding or pecuniary involvement in any undertaking, arrangement or sale in respect of which he takes part or engages in his official capacity, or in respect of which the Constitution or any statute forbids him from having any interest.

\footnotetext{
${ }^{40}$ G.R. No. 123045, November 16, 1999.

${ }^{41}$ G.R. No. 186421, April 17, 2017.

42 G.R. Nos. 218709-10, November 14, 2018.

${ }^{43}$ G.R. No. 198162, June 21, 2017.
} 
In People v. Tuanda, ${ }^{44}$ a municipal mayor was held liable by the Sandiganbayan for taking advantage of his position and granting unto himself a permit to operate and engage as a cockpit promoter. A former vice-mayor was found guilty of violating Section 3(h) in a case determined by the Sandiganbayan in 2017 after evidence revealed that she had a financial stake in the execution of the municipality's farm-to-market road programs back in 2003 in her official capacity as presiding officer of the Sangguniang Bayan (SB). ${ }^{45}$

\subsection{Bribery and Malversation}

Bribery connotes the definition of a public official exploiting his office's authority, wealth or reputation for the gain of a person in return for consideration. ${ }^{46}$ An offense cannot be considered bribery if no consideration is present. However, offenses penalized under the Anti-Graft and Corrupt Practices Act which come under any act that may not include bribery.

In 2018, a study conducted by the Office of the Ombudsman ${ }^{47}$ found out that the pattern of bribery in the Philippines is unchanged since 2013. And while there had been an increased number of reported cases of bribery and solicitation of grease money, others were still not reporting these kinds of incidents because of the low amount of bribe demanded and the perception that despite reporting the incidents, nothing will happen anyway.

On the other hand, malversation is French in origin and it is defined as the misconduct in public office, corruption, misuse of public or other funds. This term is to other criminal terms, such as embezzlement of abuse of office. ${ }^{48}$

This part discusses the modes of committing bribery and malversation.

\section{A. Direct Bribery}

Violation of this Revised Penal Code provision is committed by a public officer who, by reason of the duties of his office, is accountable for public funds or property, shall agree to do an act which constitutes a crime, in relation with the performance of his official functions, in consideration of any offer, promise, gift or present received by such officer, personally of through the intervention of another. ${ }^{49}$

Hence, direct bribery can be committed in three ways: (1) by agreeing to perform a criminal act; (2) by accepting gift to perform a non-criminal act; and (3) by agreeing to refrain from performing an official duty.

In the decisions rendered by the Sandiganbayan, a former mayor and his wife were convicted of two separate crimes of direct bribery for demanding a construction development corporation certain amounts in consideration and in exchange of the approval and release of checks representing the balance of the advance payment from which the municipality is indebted. ${ }^{50}$

\footnotetext{
${ }^{44}$ Criminal Case No. SB-17-CRM-0472, promulgated on October 15, 2019 by the Sandiganbayan $5^{\text {th }}$ Division.

${ }^{45}$ See People of the Philippines v. Budiongan and Trabajo, SB-08-CRM -0022, promulgated on December 8, 2017.

46 See Crimes Committed by Public Officers. (n.d.). Retrieved from, https://batasnatin.com/law-library/criminallaw/crimes-and-penalties/1066-title-seven-revised-penal-code-crimes-committed-by-public-officers.html

${ }^{47}$ Office of the Ombudsman. (2018). 2017 National Household Survey on Experience with Corruption in the Philippines. Retrieved December $\quad 3, \quad 2020, \quad$ from $\quad$ www.obudsman.gov.ph: https://www.ombudsman.gov.ph/docs/08\%20Resources/2017\%20National\%20Household\%20Survey\%20on\%20Experienc e\%20with\%20Corruption\%20in\%20the\%20Philippines.pdf

${ }^{48}$ See Malversation and Legal Definition. (n.d). Retrieved from, https://definitions.uslegal.com/m/malversation/

${ }^{49}$ See Title VII Chapter 2 Article 210, Revised Penal Code, approved on December 8, 1930.

${ }^{50}$ See Crim. Case No. SB-14-CRM-0226 and Crim. Case No. SB-14-CRM-0227, promulgated in July 19, 2019.
} 
In 2008, the Supreme Court upheld Sandiganbayan's decision to convict two public officers charged with direct bribery for alleging and collecting a sum from a taxi operator on account of the defendant's failure to meet their official obligation to carry out taxi unit inspections. ${ }^{51}$

\section{B. Indirect Bribery}

Indirect bribery is committed by any public officer who shall accept gifts offered to him by reason of his office. ${ }^{52}$ Here, there is no agreement to do or not to do a function-related act but the public officer simply accepted gifts offered to him by reason of his office.

In People v. Crispulo R. Truya, ${ }^{53}$ the Sandiganbayan convicted a trial prosecutor who received the amount of five hundred pesos (Php 500.000) by reason of his office and in relation to a criminal case he handled.

\section{Qualified Bribery}

Any public official who is charged with law enforcement is responsible for the crime of qualified bribery when he refrains from arresting or punishing a criminal whose offense is punishable by reclusion perpetua or death, taking into account any bid, pledge, gift or present. And if it is the public officer who asks or demands such gift or present, the penalty shall be the capital punishment or death penalty. ${ }^{54}$

\section{Corruption of Public Officials}

This crime is committed by the bribe giver or the offeror. ${ }^{55}$ To make a person liable to this crime, it is necessary that public official he gives, promises or offers bribe to is held liable to direct or indirect bribery. ${ }^{56}$

\section{E. Malversation of Public Funds}

Malversation is committed by any public official who, by reason of the mandate of his office, is accountable for public funds or property, shall appropriate, take or misappropriate; or shall consent to, by abandonment or incompetence, any other person to take such public funds or property, in whole or in part. ${ }^{57}$

In a recent case, the Sandiganbayan sustained the Regional Trial Court's (RTC) decision to convict a disbursing officer for appropriating or embezzling for her own use and benefit a public fund in the amount of more than a million pesos. ${ }^{58}$

\section{F. Technical Malversation}

\footnotetext{
${ }^{51}$ See Rolando L. Balderama v. People of the Philippines, G.R. No. 147578-85, promulgated on January 28, 2008; See also Nagal v. Armamento v. The Special Prosecutor, G.R. Nos. 147598-605, promulgated on Janurary 8, 2008.

52 See Title VII Chapter 2 Article 211, Revised Penal Code, approved on December 8, 1930.

${ }^{53}$ See Criminal Case No. 23786, promulgated on August 10, 2005.

${ }^{54}$ See Title VII Chapter 2 Article 211-A (As Added by Section 4 R.A. No. 7559), Revised Penal Code. (Note however that death penalty in the Philippines was abolished by Republic Act 9346 approved on June 24, 2006.)

${ }^{55}$ See Title VII Chapter 2 Article 212, Revised Penal Code, approved on December 8, 1930.

${ }^{56}$ See Disini v. Sandiganbayan, G.R. Nos. 169823-24, promulgated on September 11, 2013.

${ }^{57}$ See Title VII Chapter 2 Article 217, Revised Penal Code, approved on December 8, 1930.

${ }^{58}$ See People of the Philippines v. Liza S. Arisola, SB-19-A/R-0012, promulgated on August 6, 2020.
} 
Any public official who transfers any public funds or property under his administration to any public purpose other than that for which that funds or property has been intended by a statute or by an ordinance is in violation of this provision. ${ }^{59}$ This is also referred to as the unlawful budget realignment.

In a decision rendered by the Supreme Court, ${ }^{60}$ a municipal mayor who applied 10 boxes of food appropriated for feeding program to the beneficiaries of shelter assistance program is held liable for technical malversation. The Court ruled that the act of the mayor constitutes the crime of technical malversation, no matter how honorable his intentions were or how miniscule the quantity diverted for such act.

\subsection{CODE OF CONDUCT AND ETHICAL STANDARDS FOR PUBLIC OFFICIALS AND EMPLOYEES}

A study in 2016 found out that despite the existence of Republic Act 6713 (R.A. No. 6713), the questions of ethics and responsibility continue to present the Philippine government with an unprecedented challenge. ${ }^{61}$

R.A. No. 6713 maintains that the State promotes a high standard of ethics in the field of public service. Public officers and staff shall be responsible to the people at all times, performing their roles with absolute accountability, honesty, competence and allegiance, behaving with patriotism and righteousness, living humble lives and defending the public interest over the private interest. $^{62}$ This means that to follow these duties are not just mandates of the law but also of ethics and conscience. These abovementioned characteristics of public officials or employees are expected and there is no excuse for them not to observe them.

The Code clearly enumerates the do's and don'ts for government officials and employees not only in the workplace but also out. These do's and don'ts are outlined in the eight norms of conduct that must be observed by all government officials and employees. These norms or are the following: (1) commitment to public interest; (2) professionalism; (3) justness and sincerity; (4) political neutrality; (5) responsiveness to the public; (6) nationalism and patriotism (7) civic commitment; and (8) plain living. ${ }^{63}$

However, it is sad that so great a number of cases have been decided against Philippine public officials and employees in violation of this law. A good number of cases will be cited in this part.

A public-school principal was held liable for violation of Section 7 (b)(2) of R.A. No. $6713^{64}$ for actively performing the management of a private school. ${ }^{65} \mathrm{~A}$ same violation can be seen in a case of a former RTC Clerk of Court, who was fined and sternly warned by the Supreme Court for practicing law in a private manner. ${ }^{66}$

\footnotetext{
${ }^{59}$ See Title VII Chapter 2 Article 220, Revised Penal Code, approved on December 8, 1930.

${ }^{60}$ See Ysidoro v. People of the Philippines, G.R. No. 192330, promulgated on the $14^{\text {th }}$ day of November 2012.

${ }^{61}$ Aranas, A. G. (2016). Bureaucracy on Trail: Ethical Standards for Public Officials and Employees. International Journal of Current Research, 32071-32073. Retrieved December 3, 2020, from http://www.journalcra.com/sites/default/files/issuepdf/14698.pdf

62 See Section 2, R.A. No 6713

${ }^{63}$ Aranas, A.G. (2016). Bureaucracy on Trail: Ethical Standards for Public Officials and Employees.

${ }^{64}$ This section prohibits public officials and employees to engage in the private practice of their profession unless authorized by the Constitution or law, provided, that such practice will not conflict or tend to conflict with their official functions.

${ }^{65}$ See Office of the Ombudsman v. Florentina Santos, G.R. NO. 166116, promulgated on March 31, 2006.

${ }^{66}$ See Query of Atty. Karen M. Silverio-Buffe, on the prohibition from engaging in the private practice of law, A.M. No. 08-6-352-RTC, promulgated on August 19, 2009.
} 
In a case in 2017, the Ombudsman removed a city treasurer from service for dishonesty, gross incompetence and breach of Section 8(a) of the R.A. No. 6713. ${ }^{67}$ The Court of Appeals (CA) sustained the earlier decision rendered by the Ombudsman. The Supreme Court, however, rendered a new judgment of simple negligence for the petitioner for failing to accomplish her Statements of Assets, Liabilities and Net Worth (SALN) ${ }^{68}$ It should be noted that Chief Justice Renato Corona, in 2011, was found guilty by the impeachment court for failure to disclose his SALN and was removed as the highest magistrate of the Philippine Court. ${ }^{69}$

An ex-mayor, in a case for violation of Section 7 (d) of R.A. No. $6713,{ }^{70}$ admitted all the allegations against him. He was not jailed but was ordered to pay a fine. He also sought re-election during the 2016 elections but lost. ${ }^{71}$

In a decision rendered by the Supreme Court in $2014,{ }^{72}$ a deputy administrator and a director were made liable for violation of Section 5(a) of R.A. No. $6713^{73}$ in relation with Section 3(a)(2), Rule VI of the Rules Implementing R.A. No. $6713^{74}$ and was given the punishment of reprimand pursuant to Section 10(a), Rule III of Administrative Order No. $7 .^{75}$

\subsection{REPORTED CORRUPT PRACTICES OF PUBLIC OFFICIALS AND EMPLOYEES UNDER THE DUTERTE ADMINISTRATION}

Weeks before assuming to office, President Duterte said that he would not tolerate even a "whiff of corruption" from any government employee under his administration. He emphasized that in a report of even a whiff or whisper of corruption, he would immediately fire those who would be involved or place them somewhere they would not like to be. ${ }^{76}$ He said that reform would begin

67 This section orders all public officials and employees, except those who serve in an honorary capacity, laborers and casual or temporary workers, to file under oath their SALN and a Disclosure of Business Interests and Financial Connections and those of their spouses and unmarried children under eighteen (18) years of age living in their households. ${ }^{68}$ See Concepcion c. Daplas v. Department of Finance, G.R. No. 221153, promulgated on April 17, 2017.

69 Reyes, R. G. (2020). A Corona we will never forget. The Manila Times. Retrieved December 3, 2020, from https://www.manilatimes.net/2020/04/30/opinion/columnists/a-corona-we-will-never-forget/720683/

${ }^{70}$ Section 7(d) of RA 6713 forbids public officials and employees from directly or indirectly demanding or receiving from any person, in the course of their official duties or in connection with any service being controlled by, or any activity which may be influenced by the functions of their office, 'any donation, gratuity, favour, pleasure, loan or something of monetary value.'

${ }^{71}$ Marcelo, E. (2017). Ex-CamSur mayor pleads guilty to ethics violation. Philstar Global. Retrieved December 3, 2020, from https://www.philstar.com/nation/2017/11/25/1762384/ex-camsur-mayor-pleads-guilty-ethics-violation

72 See Edita S. Bueno and Milagros E. Quinajon v. Office of the Ombudsman, Napoleon S. Ronquillo, Jr., Edna G. Raña and Romeo G. Refruto, G.R. No. 191712, promulgated on September 17, 2014.

73 This section prohibits all public officials and employees shall, within fifteen (15) working days from receipt thereof, respond to letters, telegrams or other means of communications sent by the public. The reply must contain the action taken on the request.

${ }^{74}$ This section provides that in case of written requests, petitions or motions, sent by means of letters, telegrams, or the like, the official or employee in charge shall act on the same within fifteen (15) working days from receipt thereof, provided that: (a) If the communication is within the jurisdiction of the office or agency, the official or employee must: (2) Where the matter is non-routinary or the issues involved are not simple or ordinary, write a note or letter of acknowledgement, informing the interested party, petitioner or correspondent of the action to be taken or when such requests, petitions or motions can be acted upon. Where there is a need to submit additional information, requirements, or documents, the note or letter of acknowledgment shall so state, specifying reasonable period of time within which they should be submitted, and the name of the particular official or employee in charge thereof. When all the documents or requirements have been submitted to the satisfaction of the department, or office of agency concerned, the particular official or employee in charge shall inform the interested party, petitioner, or correspondent of the action to be taken and when such action or disposition can be expected, barring unforeseen circumstances.

${ }^{75}$ See Rule of Procedure of the Office of the Ombudsman.

${ }^{76}$ Ranada, P. (2016). Duterte to gov't employees: One whiff of corruption, you're out. Rappler, p. n/a. Retrieved December 4, 2020, from https://www.rappler.com/nation/duterte-government-employees-corruption 
with the Filipinos and the Filipinos in his inaugural speech in 2016, because they themselves have been their greatest enemies and should have the strength and the desire to change themselves. ${ }^{77}$

Years have passed from that promise he gave, now President Duterte, in his fourth State of the Nation Address (SONA) in 2019 was not able to hide his frustration of still not ending corruption in the government as he even wished the Big One ${ }^{78}$ to happen. He even added that corruption is found everywhere in the government and that moral recovery initiatives must be made in order to put an end to it. ${ }^{79} \mathrm{He}$ made this remark as the Philippines ranked the $113^{\text {th }}$ least corrupt nation from among 180 countries according to a report made by the Transparency International. ${ }^{80}$ In October of the year 2020, the President made another guarantee to the Filipino people that he would devote all his remaining years in office to continuously fight not only those individuals, groups and syndicates involved in illegal drugs but also those involved in corruption. He also directed the Department of Justice (DOJ) to prosecute corruption in the government as a whole. ${ }^{81}$

This part of the study narrates the biggest headlined cases of corruption under the Duterte Administration.

\section{A. The 2016 Bureau of Immigration Bribery Scandal}

In return for the release of about 600 Chinese workers working at its online gaming facility in Fontana Leisure Parks and Casino in Clark, Pampanga, two officials of the Bureau of Immigration (BI) were charged with breaching the provisions of R.A. No. 3019 for extorting Php 50 million from a gaming tycoon. ${ }^{82}$ However, the two officials pointed out in media that while it was true that they had a meeting with the gaming tycoon's associate in one popular casino hotel, and that they were offered money which they accepted, they were quick to say that this was part of a grand plan to make a strong case against the gaming tycoon for alleged payoff in the bureau. ${ }^{83}$

Not convinced with their alibi and reaffirming his pledge to fight corruption, President Duterte immediately directed the dismissal of the two BI officials who are involved in corruption, and who happened to be his brothers in a fraternity. ${ }^{84}$

In 2017, the Office of the Ombudsman ordered the filing of charges against Plunder under Republic Act No. 7080 against the two former BI officials, along with the President of the Asian Gaming Service Providers Group, Inc. ${ }^{85}$

${ }^{77}$ Gutierrez, J. (2016). Rodrigo Duterte inaugurated as Philippines President. CNN World, p. n/a. Retrieved December 4 2020, from https://edition.cnn.com/2016/06/29/asia/philippines-duterte-inauguration/index.html

78 According to the Philippine Institute of Volcanology and Seismology (PHIVOLCS), the "Big One" is a worst-case scenario of a 7.2-magnitude earthquake from the West Valley Fault, a 100-kilometer fault that runs through six cities in Metro Manila and nearby provinces. A tsunami is also foreseen in the scenario.

${ }^{79}$ Gregorio, X. (2019). From 'three to six months' to three years: Drugs, corruption still among Duterte's woes. Retrieved from CNN Philippines: https://cnnphilippines.com/news/2019/7/22/SONA-2019-Rodrigo-Dutertecorruption.html?fbclid=lwAR2

${ }^{80}$ Transparency International. (2019). Corruption Index Report 2019. Retrieved from Transparency Intertanational The global coalition against corruption: https://www.transparency.org/files/content/pages/2019_CPI_Report_EN.pdf

81 Ranada, P. (2020). Duterte orders DOJ to probe corruption 'in entire government'. Retrieved from Rappler: https://www.rappler.com/nation/duterte-orders-doj-investigate-corruption-entire-philippine-government

82 Santos, E. P. (2016). Immigration officials face graft charges over extortion scandal. CNN Philippines, p. n/a. Retrieved December 4, 2020, from https://cnnphilippines.com/news/2016/12/16/Sombero-files-graft-charges-vs.-Immigrationofficials.html

${ }^{83}$ Nicolas, F. (2016). Immigration Deputy Commissioners Argosino, Robles: Our integrity is intact. CNN Philippines, $\mathrm{p}$. n/a. Retrieved December 4, 2020, from https://cnnphilippines.com/news/2016/12/13/bureau-of-immigrationcommissioners-argosino-robles-justice-secretary-aguirre-jack-lam-sombrero.html

${ }^{84}$ ABS-CBN. (2016). Duterte fires 2 immigration deputies in bribery scandal. Retrieved December 4, 2020, from ABSCBN News: https://news.abs-cbn.com/news/12/16/16/duterte-fires-2-immigration-deputies-in-bribery-scandal

${ }^{85}$ Ombudsman. (2017). OMB indicts immigration commissioners in extortion plot for plunder. Retrieved December 4 , 2020, from Office of the Ombudsman: https://www.ombudsman.gov.ph/omb-indicts-immigration-commissioners-inextortion-plot-for-plunder/ 


\section{B. The 2017 Bureau of Customs Drug Smuggling Scandal}

The Senate Blue Ribbon Committee led by Senator Richard Gordon investigated the potential malfeasance, misfeasance, and non-feasance of the Bureau of Customs officials and employees suspected to have been involved in a shipment of shabu from China worth PHP 6.4 billion or USD 126 million in $2017 .{ }^{86}$

On the other hand, the Bureau of Customs have asked the help of the National Bureau of Investigations (NBI) and the Philippine Law Enforcement Agency (PDEA) to investigate more than 600 kilograms of shabu that they found in a Valenzuela City warehouse. No physical inspection and further documentary review was required for the containers containing the drugs to be released as the shipment was tagged "Green". ${ }^{87}$ As a result, criminal cases for violation of R.A. No 3019 were filed against several Bureau of Customs officers and employees. ${ }^{88}$

\section{The Pastillas Bribery Scandal}

In February 2020, when the pastillas modus or the facilitation of the admission of thousands of Chinese nationals who would work for the Philippine Offshore Gaming Operators (POGOs) in exchange for bribes was revealed, the Bureau of Immigration was again thrown into hot water. Immediately, owing to command responsibility, five BI officers were relieved. This pastillas is a Php 10,000 bribe from each Chinese national hidden in a paper which is alike to the country's famous pastillas before giving them to the immigration officers stationed at the airport. ${ }^{89}$

Senator Franklin Drilon, in September 2020, called for the bureau's reorganization over this pastillas scheme. He added that he was very surprised that his own colleagues apprehended the NBI legal assistance bureau head himself for allegedly taking bribe money from the BI officials involved in the pastillas modus. ${ }^{90}$ And after series of investigations, the Office of the Ombudsman, in October 2020, issued a suspension order against forty-four (44) BI officials accused of involvement in the said scheme. ${ }^{91}$

\section{Philippine Health Insurance Corporation (PhilHealth) Controversy}

Former anti-fraud officer testified in a Senate report on the suspected PhilHealth in August 2020 that the director of PhilHealth ordered him to "massage" the problem on the reportedly

\footnotetext{
${ }^{86}$ Parpan, L., \& Lardizabal, C. (2017). Senate alleges corruption and incompetence in customs bureau over biggest haul yet of shabu smuggled into PH. Retrieved December 4, 2020, from CNN Philippines: https://cnnphilippines.com/news/2017/07/31/senate-probe-customs-drugs-china-faeldon.html

87 Nolasco, M. C. (2017). SMUGGLING OF ILLICIT DRUGS AIDED BY CUSTOMS PLAYERS. WORK PRODUCT OF THE 169TH INTERNATIONAL TRAINING COURSE (pp. 59-62). Tokyo, Japan: United Nations Asia and Far East Institute for the Prevention of Crime and the Treatment of Offenders. Retrieved December 4, 2020, from United Nations Asia and Far East Institute for the Prevention of Crime and the Treatment of Offendeers: https://www.unafei.or.jp/publications/pdf/RS_No106/No106_12_IP_Philippines.pdf

88 The cases were docketed as NPS Docket No. XVI-INV-17I-00251 and NPS Docket No. XVI-INV-17I-00252. The case against the Chief was dismissed while the cases against the employees of the FED are awaiting Resolution of the Prosecutor of the Department of Justice.

${ }^{89}$ Gonzales, C. (2020). 5 immigration officers sacked over 'pastillas' bribery scheme for Pogo workers. Inquirer.Net, p. n/a. Retrieved December 4, 2020, from https://newsinfo.inquirer.net/1230159/5-immigration-officers-relieved-from-postsdue-to-pastillas-scheme

${ }^{90}$ Gotinga, J. (2020). Drilon calls for reorganization of Bureau of Immigration over 'pastillas' bribery scheme. Retrieved December 4, 2020, from Rappler: https://www.rappler.com/nation/drilon-calls-reorganization-bureau-immigrationpastillas-bribery-scheme

91 Araja, R. N. (2020). Ombudsman suspends 44 BI execs over 'pastillas' scam. Retrieved December 4, 2020, from ManilaStandard.Net: https://manilastandard.net/mobile/article/337994
} 
overpriced Covid-19 research kits. ${ }^{92} \mathrm{He}$ also alleged that because of anomalous transactions, the PhilHealth "mafia members" should be charged of what he calls the crime of the year. ${ }^{93}$

Because of the state-run agency's fiasco, the Presidential Anti-Corruption Commission (PACC) prosecuted 40 executives and officials over PhilHealth's suspected anomalies and vowed that further lawsuits would be filed immediately before the Ombudsman's office. ${ }^{94}$ PhilHealth's Chief washed hands in all the allegations but recently resigned due to his declining health condition.

\section{E. Duterte's Controversial Reappointments}

In his first three years as President, due to charges of involvement in corruption or mismanagement of public funds, Duterte had dismissed, suspended or demanded the resignation of a variety of public servants and officials. ${ }^{95}$ This firing spree include the former Department of Interior and Local Government (DILG) Secretary, Ismael Sueno ${ }^{96}$ and Department of Information and Communications Technology (DICT) Secretary, Rodolfo Salalima ${ }^{97}$ in 2017 and Department of Justice (DOJ) Secretary, Vitaliano Aguirre II $^{98}$ in 2018.

Nevertheless, in the wake of these firings, significant questions were raised regarding Duterte's anti-corruption drive. The infamous "recycling" of officials was flagged by multiple reports. ${ }^{99}$

In 2018, this so called recycling includes the re-appointments of the controversial former BOC Commissioner, Nicanor Faeldon, who resigned due to alleged involvement in a shabu scandal, as Civil Defense Deputy Administrator; the former director in the BOC Milo Maestrecampo, who resigned due to alleged corruption and collusion with drug smugglers, as Assistant Director General of the Civil Aviation Authority; the former deputy commissioner of the BOC, Gerardo Gambala, who also resigned due to alleged corruption and collusion with drug smugglers, as Director of the Office of Transport Security; the former commissioner Manuel Serra, who was fired due to excessive travels and foreign junkets, as a Governing Board member of the Philippine Coconut Authority; the former commissioner of the Social Security System Jose Gabriel La Vina, who was fired due to abuse of public funds, as Undersecretary of the DOT; and the former district collector of NAIA, who was fired for allegedly accepting grease money from BOC and involvement in a shabu scandal, as Assistant Commissioner of the BOC. ${ }^{100}$

\footnotetext{
92 Magsambol, B. (2020). Resigned officer says PhilHealth chief ordered him to 'massage' overpriced testing kits issue. Retrieved December 4, 2020, from Rappler: https://www.rappler.com/nation/ex-philhealth-officer-says-morales-orderedmassage-overpriced-covid-19-testing-kits-issue

${ }^{93}$ Jalea, G., \& Peralta, J. (2020). Whistleblower claims P15 billion stolen by PhilHealth execs in fraud schemes. Retrieved December 4, 2020, from CNN Philippines: https://cnnphilippines.com/news/2020/8/4/PhilHealth-P15-billion-stolen-mafiaexecs.html

${ }^{94}$ See Lopez, M. L. (2020). PACC probing 40 names in PhilHealth scandal, filing more cases 'very soon'. Retrieved $4^{\text {th }}$ day of December 2020, from https://www.cnnphilippines.com/news/2020/9/28/PACC-PhilHealth-more-cases-coming.html

95 See Purugganan, J. (2019). Selective Transparency, Inconsistent Accountability:Unpacking Duterte's Anti-Corruption Campaign. Retrieved December 5, 2020, from Focus on the Global South: https://focusweb.org/selective-transparencyinconsistent-accountabilityunpacking-dutertes-anti-corruption-campaign/

96 See Legaspi, A., \& Macas, T. (2017). Sueno fired from DILG post. Retrieved December 5, 2020, from GMA News Online: https://www.gmanetwork.com/news/news/nation/605738/sueno-fired-from-dilg-post/story/

97 See Valente, C. (2017, September 28). I asked Salalima to resign - Duterte. Retrieved December 5, 2020, from The Manila Times: https://www.manilatimes.net/2017/09/28/news/latest-stories/asked-salalima-resign-duterte/353470/

${ }^{98}$ See Ballaran, J. (2018). Aguirre resigned due to public's loss of trust in him - official. Retrieved December 5, 2020, from Inquirer.Net: https://newsinfo.inquirer.net/980581/aguirre-resigned-due-to-publics-loss-of-trust-in-him-official

${ }^{99}$ Purugganan, J. Selective Transparency, Inconsistent Accountability:Unpacking Duterte's Anti-Corruption Campaign

100 See Bueza, M. (2018,). Notable Duterte admin exits and reappointments. Retrieved December 5, 2020, from Rappler: https://specials.rappler.com/newsbreak/videos-podcasts/205964-firing-resignations-reappointments-duterteadministration/index.html
} 


\section{CONCLUSION}

The presence of laws in the Philippines that penalize corrupt practices discourage the misdeeds that could be perpetrated by government officials and workers. Adding to these deterrents is the President's powerful political will and his promise to finally end corruption. A large number of crooked politicians and staff have either been suspended, resigned or substituted. A pile of lawsuits is still pending for prosecution or trial before the Sandiganbayan, the Office of the Ombudsman, and the ordinary and administrative courts.

But the Philippines also has a lot of mess to clear up, as a region swarmed with cases of corruption. As seen in the country's history, a huge number of government officials and employees have been involved in corrupt practices. There were some who have been jailed, while others were meted the penalty of perpetual disqualification to hold any public office.

However, corruption is still rampant. Corrupt individuals are still around as if a predator looking to devour a prey. Until the last corrupt official or employee has been caught and punished, the promise of the President to end corruption still remains to be a broken vow.

With this result of study, researches about the various anti-corruption laws in the Philippines can be made soon. Researches such as the extent of the laws' implementation, effectiveness, and the like can be made.

\section{REFERENCES}

ABS-CBN. (2016, December 17). Duterte fires 2 immigration deputies in bribery scandal. Retrieved December 4, 2020, from ABS-CBN News: https://news.abscbn.com/news/12/16/16/duterte-fires-2immigration-deputies-in-bribery-scandal

Araja, R. N. (2020, October 28). Ombudsman suspends 44 BI execs over 'pastillas' scam. Retrieved December 4, 2020, from ManilaStandard.Net: https://manilastandard.net/mobile/article/3379 94

Aranas, A. G. (2016, May 31). Bureaucracy on Trail: Ethical Standards for Public Officials and Employees. International Journal of Current Research, 32071-32073. Retrieved December 3, 2020, from http://www.journalcra.com/sites/default/files/i ssue-pdf/14698.pdf

Ballaran, J. (2018, April 6). Aguirre resigned due to public's loss of trust in him - official. Retrieved December 5, 2020, from Inquirer.Net:

https://newsinfo.inquirer.net/980581/aguirreresigned-due-to-publics-loss-of-trust-in-himofficial

Batalla, E. V. (2020, June 10). Grand corruption scandals in the Philippines. Emerald Insight, 23(1), 73-86. doi:https://doi.org/10.1108/PAP11-2019-0036
Buan, L. (2018, May 8). Ombudsman probes P60million DOT-Tulfo controversy. Retrieved December 4, 2020, from Rappler: https://www.rappler.com/nation/ombudsmaninvestigation-wanda-teo-tourism-departmenttulfo-controversy

Bueza, M. (2018, June 29). Notable Duterte admin exits and reappointments. Retrieved December 5, 2020, from Rappler: https://specials.rappler.com/newsbreak/videos -podcasts/205964-firing-resignationsreappointments-duterteadministration/index.html

Campanilla, M. B. (2019). Criminal Law Reviewer Volume II. Manila: Rex Printing Company Inc.

Carandang, M. A., \& Balboa-Cahig, J. A. (2018). COUNTERING CORRUPTION IN THE PHILIPPINES: PROTOTYPES AND REINFORCING MEASURES. TWELFTH REGIONAL SEMINAR ON GOOD GOVERNANCE FOR SOUTHEAST ASIAN COUNTRIES (pp. 103-113). Tokyo City, Japan: United Nations Asia and Far East Institute for the Prevention of Crime and the Treatment of Offenders. Retrieved November 29, 2020, from https://www.unafei.or.jp/publications/pdf/GG 12/21_GG12_CP_Philippines.pdf 
CNN Philippines Staff. (2018, May 3). President's office investigating officials involved in P60M DOT-PTV deal controversy. Retrieved December 4, 2020, from CNN Philippines: https:/cnnphilippines.com/news/2018/05/03/ DOT-Tourism-Wanda-Teo-PTV-4-Tulfo.html

CNN Staff, P. (2017, October 23). Malacañang: Bautista's resignation 'effective immediately. Retrieved November 30, 2020, from CNN Philippines:

https://cnnphilippines.com/news/2017/10/23/ malcanang-andres-bautista-resignationeffective-immediately.html

Conde, C. H. (2007, October 1). Benjamin Abalos, Filipino elections official, resigns in a scandal that may threaten Arroyo. The New York Times, p. not applicable. Retrieved November 30, 2020, from https://www.nytimes.com/2007/10/01/world/a sia/01iht-phils.1.7696723.html

Coronel, S. S., \& Kawal-Tirol, L. (2002). Investigating Corruption: A Do-It-Yourself Guide. Manila: Philipine Center for Investigative Journalism.

Corrales, N. (2016, March 20). Duterte: 'I can't promise heaven, but I will stop corruption'. Retrieved November 27, 2020, from Inquirer.Net:

https://newsinfo.inquirer.net/775352/duterte-icant-promise-heaven-but-i-will-stopcorruption

Crimes Committed by Public Officers. (n.d.). Retrieved from Batas Natin: https://batasnatin.com/lawlibrary/criminal-law/crimes-andpenalties/1066-title-seven-revised-penal-codecrimes-committed-by-public-officers.html

Cupin, B. (2018). LOOK: Why the House panel wants to impeach Sereno. Manila: Rappler. Retrieved November 30, 2020, from https://www.rappler.com/nation/serenoarticles-of-impeachment-house

Diaz, J. (2007, September 2008). Abalos faces impeachment. PhilStar Global, p. not applicable. Retrieved November 30, 2020, from

https://www.philstar.com/headlines/2007/09/2 8/16994/abalos-faces-impeachment

EIU. (2001, June 1). The Economist Intelligence Unit. Retrieved November 30, 2020, from The Economist Group: http://country.eiu.com/article.aspx ?articleid=1 $628143747 \&$ Country=Philippines\&topic $=$ Poli tics\&subtopic=Recent+developments\&subsub topic $=$ The + political + scene: + Merceditas + Guti errez+resigns+as+ombudsman

Endriga, J. N. (1979, July-October). Historical Notes on Graft and Corruption. Philippine Journal O/Public Administration, XXIII(3 and 4), 241254. Retrieved November 28, 2020, from https://pssc.org.ph/wp-content/psscarchives/Philippine\%20Journal\%20of\%20Pub lic\%20Administration/1979/Num\%2034/06_Historical\%20Notes\%20on\%20Graft\%2 0and\%20Corruption\%20in\%20the\%20Phils..p df

Ferrer, E. S., \& De Dios, R. D. (2001, January-June). Corruption in the Philippines: Framework and Context. Philippine Journal of Public Policy, 5(1), 1-42. Retrieved November 28, 2020, from https://cids.up.edu.ph/wpcontent/uploads/Corruption-in-thePhilippines-vol.5-no.1-Jan-June-2001-2.pdf

Gonzales, C. (2020, February 18). 5 immigration officers sacked over 'pastillas' bribery scheme for Pogo workers. Inquirer.Net, p. n/a. Retrieved December 4, 2020, from https://newsinfo.inquirer.net/1230159/5immigration-officers-relieved-from-posts-dueto-pastillas-scheme

Gotinga, J. (2020, September 22). Drilon calls for reorganization of Bureau of Immigration over 'pastillas' bribery scheme. Retrieved December 4, 2020, from Rappler: https://www.rappler.com/nation/drilon-callsreorganization-bureau-immigration-pastillasbribery-scheme

Gregorio, X. (2019, July 22). From 'three to six months' to three years: Drugs, corruption still among Duterte's woes. Retrieved from CNN Philippines:

https://cnnphilippines.com/news/2019/7/22/S

ONA-2019-Rodrigo-Dutertecorruption.html?fbclid=lwAR2

Gutierrez, J. (2016, June 30). Rodrigo Duterte inaugurated as Philippines President. CNN World, p. n/a. Retrieved December 4, 2020, from https://edition.cnn.com/2016/06/29/asia/philip pines-duterte-inauguration/index.html

History and Origin. (n.d.). Retrieved from Office of the Ombudsman:

https://www.ombudsman.gov.ph/aboutus/history/

Impeachment: A Political and Historical Guide. (2014). Retrieved from GOV.PH: https://www.gov.ph/documents/20147/233614 
/ImpeachmentPrimer.pdf/72801f41-71e1ae60-d5bb-c69dbf622994?version $=1.0$

Jalea, G., \& Peralta, J. (2020, August 4). Whistleblower claims P15 billion stolen by PhilHealth execs in fraud schemes. Retrieved December 4 , 2020, from CNN Philippines: https://cnnphilippines.com/news/2020/8/4/Phil Health-P15-billion-stolen-mafia-execs.html

Legaspi, A., \& Macas, T. (2017, April 4). Sueno fired from DILG post. Retrieved December 5, 2020, from GMA News Online: https://www.gmanetwork.com/news/news/nati on/605738/sueno-fired-from-dilg-post/story/

Lopez, M. L. (2020, September 28). PACC probing 40 names in PhilHealth scandal, filing more cases 'very soon'. Retrieved December 4, 2020, from CNN Philippines: https://www.cnnphilippines.com/news/2020/9/ 28/PACC-PhilHealth-more-casescoming.html

Magsambol, B. (2020, August 4). Resigned officer says PhilHealth chief ordered him to 'massage' overpriced testing kits issue. Retrieved December 4, 2020, from Rappler: https://www.rappler.com/nation/ex-philhealthofficer-says-morales-ordered-massageoverpriced-covid-19-testing-kits-issue

Malcolm, G. A. (1926). Philippine Constitutional Law 2nd Edition. Manila: P.I. \& Rochester, NY, Lawyers Co-op.

Malversation and Legal Definition. (n.d). Retrieved from US Legal: https://definitions.uslegal.com $/ \mathrm{m} /$ malversation /

Marcelo, E. (2017, November 25). Ex-CamSur mayor pleads guilty to ethics violation. Philstar Global, p. n/a. Retrieved December 3, 2020, from

https://www.philstar.com/nation/2017/11/25/1

762384/ex-camsur-mayor-pleads-guiltyethics-violation

Merez, A., Quintos, P., Reformina, I., \& Manabat, J. (2018). Supreme Court ousts Chief Justice Sereno. Manila: ABS-CBN News. Retrieved November 30, 2020, from https://news.abscbn.com/news/05/11/18/supreme-court-oustschief-justice-sereno

Nachura, A. E. (2016). Outline Reviewer in Political Law. Quezon City: VJ Graphic Arts, Inc.

Nicolas, F. (2016, December 13). Immigration Deputy Commissioners Argosino, Robles: Our integrity is intact. CNN Philippines, p. n/a.
Retrieved December 4, 2020, from https://cnnphilippines.com/news/2016/12/13/b ureau-of-immigration-commissionersargosino-robles-justice-secretary-aguirre-jacklam-sombrero.html

Nolasco, M. C. (2017, May). SMUGGLING OF ILLICIT DRUGS AIDED BY CUSTOMS PLAYERS. WORK PRODUCT OF THE 169TH INTERNATIONAL TRAINING COURSE (pp. 59-62). Tokyo, Japan: United Nations Asia and Far East Institute for the Prevention of Crime and the Treatment of Offenders. Retrieved December 4, 2020, from United Nations Asia and Far East Institute for the Prevention of Crime and the Treatment of Offendeers:

https://www.unafei.or.jp/publications/pdf/RS No106/No106_12_IP_Philippines.pdf

Office of the Ombudsman. (2018, November 30). 2017 National Household Survey on Experience with Corruption in the Philippines. Retrieved December 3, 2020, from www.obudsman.gov.ph:

https://www.ombudsman.gov.ph/docs/08\%20 Resources/2017\%20National\%20Household\% 20Survey\%20on\%20Experience $\% 20$ with $\% 20$ Corruption\%20in\%20the\%20Philippines.pdf

Ombudsman. (2017, October 27). OMB indicts immigration commissioners in extortion plot for plunder. Retrieved December 4, 2020, from Office of the Ombudsman: https://www.ombudsman.gov.ph/omb-indictsimmigration-commissioners-in-extortion-plotfor-plunder/

Parpan, L., \& Lardizabal, C. (2017, July 31). Senate alleges corruption and incompetence in customs bureau over biggest haul yet of shabu smuggled into PH. Retrieved December 4, 2020, from CNN Philippines: https://cnnphilippines.com/news/2017/07/31/s enate-probe-customs-drugs-chinafaeldon.html

Press, A. (2017, March 15). Philippine lawmakers kill impeachment case against Duterte. Retrieved November 30, 2020, from USA Today: https://www.usatoday.com/story/news/world/2 017/05/15/philippine-lawmakers-killimpeachment-case-againstduterte/101700122/

Purugganan, J. (2019, May 8). Selective Transparency, Inconsistent Accountability:Unpacking Duterte's Anti-Corruption Campaign. Retrieved December 5, 2020, from Focus on the Global South: 
https://focusweb.org/selective-transparencyinconsistent-accountabilityunpackingdutertes-anti-corruption-campaign/

R.C.C. NO. 40 Saturday, July 26, 1986. (n.d.). Retrieved from Official Gazette: https://www.officialgazette.gov.ph/1986/07/2 6/r-c-c-no-40-saturday-july-26-1986/

Ranada, P. (2016, June 22). Duterte to gov't employees: One whiff of corruption, you're out. Rappler, p. n/a. Retrieved December 4, 2020 , from https://www.rappler.com/nation/dutertegovernment-employees-corruption

Ranada, P. (2020, October 27). Duterte orders DOJ to probe corruption 'in entire government'. Retrieved from Rappler: https://www.rappler.com/nation/duterteorders-doj-investigate-corruption-entirephilippine-government

Reyes, R. G. (2020, April 30). A Corona we will never forget. The Manila Times, p. n/a. Retrieved December 3, 2020, from https://www.manilatimes.net/2020/04/30/opini on/columnists/a-corona-we-will-neverforget/720683/

Risk and Compliance Portal. (2020, May ). Retrieved from Gan Integrity: https://www.ganintegrity.com/portal/countryprofiles/the-philippines/

Santos, E. P. (2016, December 16). Immigration officials face graft charges over extortion scandal. CNN Philippines, p. n/a. Retrieved December 4, 2020, from https://cnnphilippines.com/news/2016/12/16/S ombero-files-graft-charges-vs.-Immigrationofficials.html

Seigel, J. (2003, March 3). Philippine citizens overthrow President Joseph Estrada (People Power II), 2001. Retrieved November 30,
2020, from Global Nonviolent Action Database:

https://nvdatabase.swarthmore.edu/content/phi lippine-citizens-overthrow-president-josephestrada-people-power-ii-2001

Tejada, A. P. (2016, February 20). Duterte vows to end criminality in 3 months. Retrieved December 5, 2020, from The Philippine Star: https://www.philstar.com/headlines/2016/02/2 0/1555349/duterte-vows-end-criminality-3months

Trading Economics. (2019). Philippines Corruption Rank 1995-2019. Retrieved from https://tradingeconomics.com/philippines/corr uption-rank

Transparency International. (2019). Corruption Index Report 2019. Retrieved from Transparency Intertanational The global coalition against corruption:

https://www.transparency.org/files/content/pa ges/2019_CPI_Report_EN.pdf

Uy, J. R., Santos, T. G., \& Nonato, V. F. (2017, October 11). House impeaches Comelec chief after he said he was resigning. Inquirer.Net, p. not applicable. Retrieved November 30, 2020, from https://newsinfo.inquirer.net/937198/housevotes-to-impeach-bautista

Valente, C. (2017, September 28). I asked Salalima to resign - Duterte. Retrieved December 5, 2020, from The Manila Times: https://www.manilatimes.net/2017/09/28/news /latest-stories/asked-salalima-resignduterte/353470/

Villamor, F. (2017, March 16). Philippine Lawmaker Moves to Impeach Duterte. The New York Times, p. not applicable. Retrieved November 30, 2020, from https://www.nytimes.com/2017/03/16/world/a sia/philippines-duterte-impeachment-.html 